\title{
Measurements of lipid \\ peroxidation and $\alpha$-tocopherol destruction in vitro and in vivo and their significance in connexion with the biological function of vitamin $E$
}

\author{
By A. T. DIPLOCK, M. A. CAW'THORNE, ELSPETH A. MURRELL, \\ J. GREEN AND J. BUNYAN \\ Walton Oaks Experimental Station, Vitamins Ltd, Tadworth, Surrey \\ (Received 20 November I967-Accepted I 5 February I968)
}

\begin{abstract}
I. Lipid peroxides have been measured by a micro-iodimetric method in pancreas, lung, adrenal, leg muscle, spleen, brain, small intestine and uterus of vitamin E-deficient and vitamin E-supplemented rats. There were no differences due to the vitamin $\mathrm{E}$ status of the rats. 2. The decay of $\left[{ }^{14} \mathrm{C}\right] \mathrm{D}-\alpha$-tocopherol in peroxidizing methyl oleate, maize oil methyl esters and cod-liver oil methyl esters was studied at $90^{\circ}$. When the decrease in tocopherol was plotted against increase in peroxide value for each ester preparation, it was found that, the greater the degree of unsaturation of the substrate, the less was the amount of tocopherol destroyed at any peroxide value attained before the end of the induction period. When the decay of tocopherol was plotted against time, however, the greater the degree of unsaturation of the substrate, the greater was the amount of tocopherol destroyed at any given time before the end of the induction period,

3. The significance of these results in connexion with the biological function of vitamin $\mathbf{E}$ is discussed.
\end{abstract}

Bunyan, Murrell, Green \& Diplock ( 1967 ) found that the concentration of lipid peroxides remained constant in several tissues of the rat regardless of its intake of unsaturated fat and vitamin $\mathrm{E}$. We have now measured lipid peroxides in several other tissues of the rat and have studied the effect of vitamin $\mathrm{E}$ on them. Our findings, both previously and in this paper, seem incompatible with the idea that generalized lipid peroxidation occurs in tissues in the absence of vitamin $\mathrm{E}$ or that the role of $\alpha$-tocopherol is that of a biological antioxidant. However, other workers (Witting, $\operatorname{Ig} 65 a, b$;

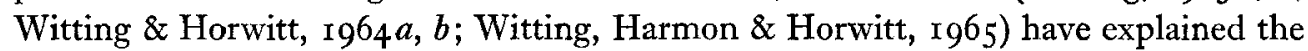
effects of dietary unsaturated fat on vitamin $E$ deficiency disease in terms of the 'peroxidizability' of the dietary fatty acids incorporated into tissues and have attempted to treat the relationship between vitamin $\mathrm{E}$ and lipid in vivo and in vitro as mechanistically and kinetically identical. We have therefore investigated certain aspects of the relationship between fatty acid peroxidation and $\alpha$-tocopherol in vitro and discuss in this paper the relevance of the findings to the problem of vitamin $E$ function in vivo.

\section{EXPERIMENTAL AND RESULTS}

\section{Methods}

Estimation of lipid peroxides in animal tissues. The general methods were as described by Bunyan et al. ( 1967 ), but the method for the extraction of tissue lipids was altered. The tissue was macerated in 19 volumes of chloroform-methanol solution $(2: \mathrm{I}, \mathrm{v} / \mathrm{v})$ 
(Folch, Lees \& Stanley, 1957), but the original procedure for washing out the nonlipid material was modified. Calculated volumes of methanol $(6.3 \mathrm{ml} / \mathrm{g}$ tissue) and water ( $10.6 \mathrm{ml} / \mathrm{g}$ tissue) were added and, after shaking, the lipids were recovered from the chloroform layer of the resultant biphasic system as described by Bligh \& Dyer (1959).

Separations of lipids and lipid peroxides by thin-layer chromatography. The methods described by Oette (1965) were followed. Layers of $0.3 \mathrm{~mm}$ of silica gel G (E. Merck AG, Darmstadt) were prepared. The solvent systems used were diethyl ether-light petroleum (boiling range, $\left.40-60^{\circ}\right)(45: 55, \mathrm{v} / \mathrm{v})$, chloroform-methanol-water $(75: 25$ : $4 \cdot 2, \mathrm{v} / \mathrm{v})$ and diethyl ether-acetic acid $(98: 2, \mathrm{v} / \mathrm{v})$. Lipids were identified by means of iodine vapour, phospholipids by the acid molybdate reagent described by Oette (1965) and lipid peroxides by the starch-iodide reagent.

Diets. Diet G $15 \mathrm{~F}$ was as described by Cawthorne, Diplock, Muthy, Bunyan, Murrell \& Green (1967) and contained $15 \%$ casein and $5 \%$ lard. Diet $\mathrm{G}_{15} \mathrm{~F}+\mathrm{E}$ consisted of diet G $5 \mathrm{~F}$ with the addition of $100 \mathrm{ppm} \mathrm{D-} \alpha$-tocopheryl acetate.

Peroxidation of fatty acid esters in vitro and measurement of $\left[{ }^{14} \mathrm{C}\right] \mathrm{D}-\alpha-$ tocopherol. $\left[{ }^{14} \mathrm{C}\right] \mathrm{D}-\alpha$-Tocopherol and purified vitamin E-free methyl oleate (OLME), maize oil methyl esters (MOME) and cod-liver oil methyl esters (CLOME) were prepared as described by Green, Diplock, Bunyan, McHale \& Muthy (1967). The initial peroxide values of the esters were about 3 . Solutions of the tocopherol in each ester preparation were made under nitrogen to give a final concentration of $100 \mu \mathrm{g}$ (1000 dps)/ml. Several samples $(3 \mathrm{ml})$ of each solution were dispensed into standard $50 \mathrm{ml}$ glass beakers and were placed together at $90 \pm 0.2^{\circ}$ in a fan-draft oven. At intervals, depending on the estimated rate of peroxidation of each ester, samples were withdrawn and rapidly cooled to room temperature. A I ml portion was transferred to a stoppered tube containing I mg unlabelled $\mathrm{D}$ - $\alpha$-tocopherol, dissolved in a few drops of light petroleum (boiling range $60-80^{\circ}$ ) and this solution was stored at $-20^{\circ}$ under $\mathrm{N}_{2}$ until it was analysed for tocopherol. Another I $\mathrm{ml}$ portion of the original $3 \mathrm{ml}$ sample was taken under $\mathrm{N}_{2}$ and used immediately for the determination of peroxide value (Green et al. I967).

The $\alpha$-tocopherol content of each sample was determined after saponification, column chromatography on Decalso $\mathrm{F}$, two-dimensional paper chromatography, elution of the $\alpha$-tocopherol spot and subsequent liquid scintillation counting of ${ }^{14} \mathrm{C}$ by the methods described previously (Green et al. 1967).

\section{Lipid peroxides in tissues of vitamin E-deficient and vitamin E-supplemented rats}

Table I shows the results for pancreas, lung, adrenal, leg muscle, spleen, brain, small intestine and uterus. In agreement with our results on other tissues (Bunyan et al. 1967), vitamin E deficiency did not increase the concentration of lipid peroxides in the eight tissues examined. Bunyan et al. (1967) discussed the remarkably constant lipid peroxide values of tissues other than adipose tissue and concluded that they were not artefactual. In order to confirm this, extracts of adipose tissue $(7 \mathrm{mg})$ and liver $(7 \mathrm{mg})$ were examined by thin-layer chromatography (Oette, 1965 ). Lipid peroxides 
were identified in the triglyceride and phospholipid fractions of livers from rats given the casein-lard diet $\mathrm{G}_{15} \mathrm{~F}$ and of adipose tissue from rats given the $20 \%$ casein diet described by Green et al. (1967) with the addition of $10 \%$ CLOME. We found previously (Bunyan $e t$ al. I967) that there was a peroxide value of less than $3 \mu$-equiv./g in adipose tissue of rats given the $5 \%$ lard diet $\mathrm{G}_{5} \mathrm{~F}$. When extracts equivalent to $7 \mathrm{mg}$ of this tissue were chromatographed, peroxides were not observed, indicating according to the method's known sensitivity a peroxide value of less than $6 \mu$-equiv./g. These results support the quantitative results of Bunyan et al. (1967) and confirm the nature of the substances measured as true lipid peroxides.

Table I. Lipid peroxides in the tissues of vitamin E-deficient and vitamin E-supplemented rats

(The rats used were 9 months old and had been given diets G 15 F or G ${ }_{5} F+E$ (see p. 466) from weaning)

\begin{tabular}{|c|c|c|c|}
\hline & & \multicolumn{2}{|c|}{ Lipid peroxides ( $\mu$-equiv./g)* } \\
\hline Tissue & Sex & $\begin{array}{l}\text { Vitamin E-deficient } \\
\text { rats }\end{array}$ & $\begin{array}{l}\text { Vitamin E-supple- } \\
\text { mented rats }\end{array}$ \\
\hline Pancreas & $\begin{array}{l}0 \\
0 \\
+ \\
\text { 인 }\end{array}$ & $\begin{array}{l}0.7(5) \\
0.9(3) \\
0.3(5)\end{array}$ & $\begin{array}{l}2 \cdot 6(3) \\
0 \cdot 9(3) \\
0 \cdot 3(3)\end{array}$ \\
\hline Lung & \begin{tabular}{l}
\multirow{3}{0}{} \\
0
\end{tabular} & $\begin{array}{l}0.8(2) \\
I \cdot I(2)\end{array}$ & $\begin{array}{l}I \cdot 2(2) \\
0.5(2)\end{array}$ \\
\hline Adrenal & $\begin{array}{l}0 \\
0 \\
0\end{array}$ & $\begin{array}{l}3 \cdot 7(5) \\
1 \cdot 5(8)\end{array}$ & $\begin{array}{l}5 \cdot 4(9) \\
1 \cdot 7(9)\end{array}$ \\
\hline Leg muscle & $\begin{array}{l}\hat{\partial} \\
\text { 우 }\end{array}$ & $\begin{array}{l}0.8(2) \\
0.5(2)\end{array}$ & $\begin{array}{l}1.0(2) \\
0.7(2)\end{array}$ \\
\hline Spleen & $\begin{array}{l}\hat{0} \\
0\end{array}$ & $\begin{array}{l}I \cdot I(3) \\
0.8(2)\end{array}$ & $\begin{array}{l}2 \cdot 3(3) \\
0 \cdot 4(2)\end{array}$ \\
\hline Brain & $\begin{array}{l}0 \\
9\end{array}$ & $\begin{array}{l}I \cdot 2(2) \\
I \cdot 2(2)\end{array}$ & $\begin{array}{l}1 \cdot 3(2) \\
1 \cdot 6(2)\end{array}$ \\
\hline Small intestine & $\begin{array}{l}\partial \\
9\end{array}$ & $\begin{array}{l}0.5(2) \\
0.8(2)\end{array}$ & $\begin{array}{l}1.0(2) \\
0.6(2)\end{array}$ \\
\hline Uterus & 오 & $0.7(3), 0.6(3)$ & $0.8(3), 0.8(3)$ \\
\hline
\end{tabular}

* The figures in parentheses indicate the number of rats whose tissues were combined to give th result shown. Each lot of rats provided one tissue only. A total of fifty-three deficient and fifty-four supplemented rats were tested.

\section{Lipid peroxidation and $\alpha$-tocopherol destruction in vitro}

Although several studies have been made (Witting \& Horwitt, 1964a, $b$; Witting, $1965 a, b)$ on the relationship between vitamin $\mathrm{E}$ deficiency disease and the degree of unsaturation of dietary lipid, very little is in fact known about the kinetics of the oxidative decay of $\alpha$-tocopherol in substrates of differing degrees of unsaturation. Lips (1957) made the only such study, although his method of tocopherol analysis must now be considered inadequate to obtain proper kinetics (Society for Analytical Chemistry: Analytical Methods Committee, 1959), and his results were too few for a full examination of the problem. In view of the importance of these kinetics to the postulate that $\alpha$-tocopherol functions as an antioxidant in vivo, we have determined 
them by studying the decay of radioactive $\alpha$-tocopherol, which can be measured with a high degree of accuracy, during the inhibited peroxidation in vitro of methyl oleate (OLME), maize oil methyl esters (MOME) and cod-liver oil methyl esters (CLOME). The ester preparations, each containing $100 \mu \mathrm{g}\left[{ }^{14} \mathrm{C}\right] \mathrm{D}-\alpha$-tocopherol/ml, were allowed to peroxidize under identical conditions at $90^{\circ}$. Figs. I and 2 show the results. In Fig. I the decrease in tocopherol was plotted against the increase in peroxide value for

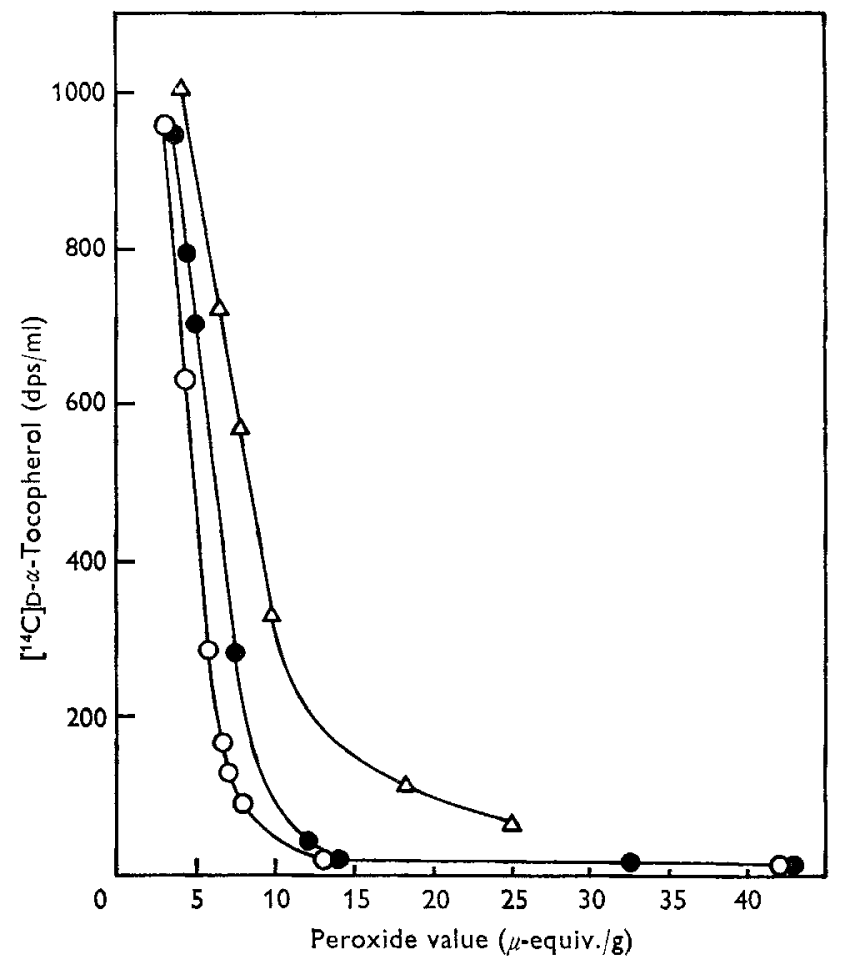

Fig. I. Decay of $\left[{ }^{14} \mathrm{C}\right] \mathrm{D}-\alpha$-tocopherol measured against increase in peroxidation of fatty acid methyl esters, with tocopherol at an initial concentration and activity of $100 \mu \mathrm{g}(1000 \mathrm{dps}) / \mathrm{ml}$. Peroxidations were carried out at $90^{\circ}$ in a fan-draft oven. $\mathrm{O}-\mathrm{O}$, methyl oleate (OLME); - - maize oil methyl esters (MOME); $\triangle-\triangle$, cod-liver oil methyl esters (CLOME).

each ester. The results confirm the statement of Witting $(1965 a, b)$ that the greater the degree of unsaturation of the substrate, the less is the amount of tocopherol destroyed at any peroxide value attained before the end of the induction period. However, when tocopherol decay was plotted as a function of time (Fig. 2), the greater the degree of unsaturation of the substrate, the greater was the amount of tocopherol destroyed at any particular time before the end of the induction period.

\section{DISCUSSION}

Opinion is divided as to the role of vitamin $\mathrm{E}$ in animals. Some workers consider that it has a special biochemical function in some way related to that of selenium; others consider that it is simply a biological antioxidant, the function of which is to 
prevent random, proliferating processes of lipid peroxidation that would otherwise cause widespread damage to tissue lipids and cellular structures (Tappel, 1962). Witting \& Horwitt $(1964 a, b)$ and Witting $(1965 a, b)$ consider all vitamin $\mathrm{E}$ and Se deficiency diseases as due to this cause and have used the antioxidant theory as the theoretical basis for an exhaustive study of the development of one particular disease, muscular dystrophy in the rat. They found that the speed of onset of dystrophy was related to the degree of unsaturation of the dietary lipid, that is, its 'peroxidizability'

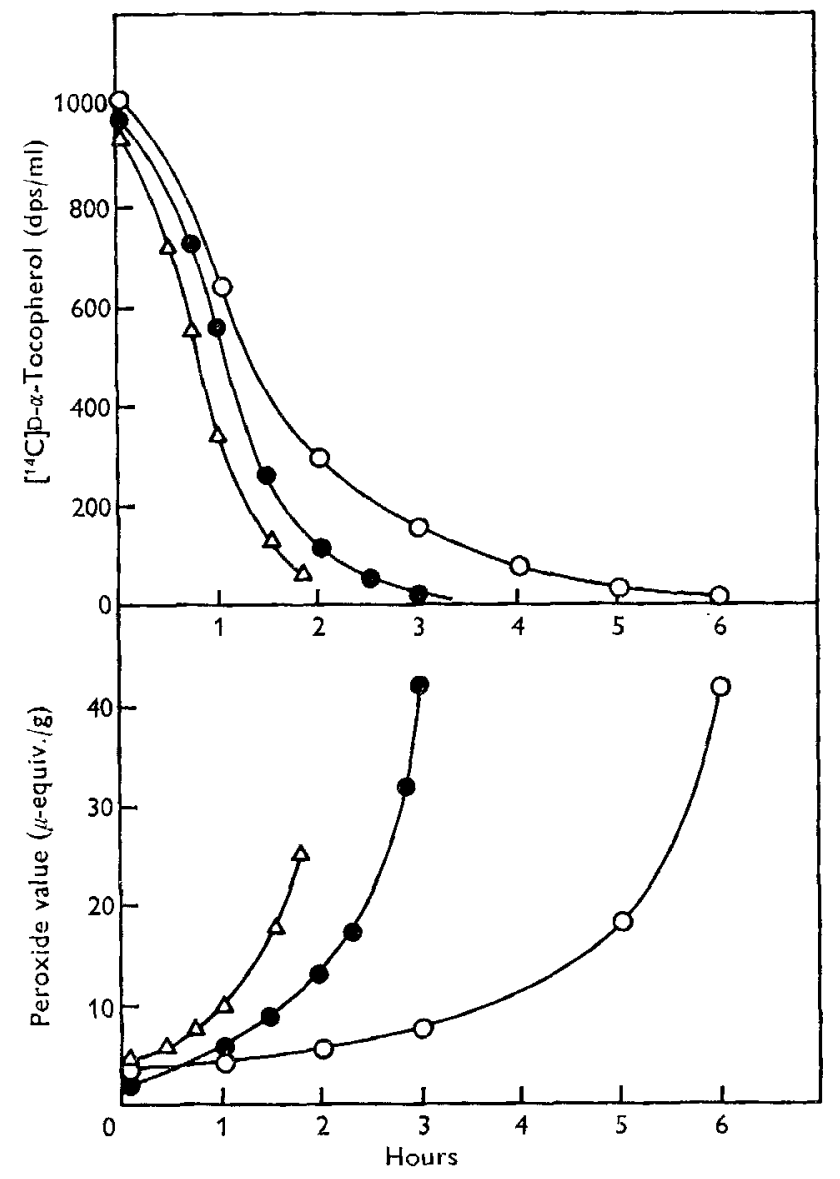

Fig. 2. Upper curve: rate of decay of $\left[{ }^{14} \mathrm{C}\right] \mathrm{D}-\alpha$-tocopherol in peroxidizing fatty acid methyl esters at an initial concentration and activity of $100 \mu \mathrm{g}$ (rooo dps)/ml. Lower curve: rate of increase in peroxide value of fatty acid methyl esters in the presence of D- $\alpha$-tocopherol at an initial concentration of $100 \mu \mathrm{g} / \mathrm{ml}$. Peroxidations were cartied out at $90^{\circ}$ in a fan-draft oven. $\mathrm{O}-\mathrm{O}$, methyl oleate (OLME); - - maize oil methyl esters (MOME); $\triangle-\triangle$, cod-liver oil methyl esters (CLOME).

measured in terms of the relative maximum rates of peroxidation of its component fatty acids in vitro. They concluded (i) that the effect of unsaturated dietary fat in accelerating the onset of dystrophy must be due to increasing 'lipid peroxidation' in 
vivo, and (ii) that 'in vitro lipid autoxidation and in vivo lipid peroxidation are kinetically comparable, whether uninhibited or antioxidant inhibited, since the rate limiting reaction in both cases depends on the structure of the polyunsaturated fatty acids' (Witting, 1965a).

It is axiomatic to the antioxidant-inhibited peroxidation process in vitro that peroxide formation is always to some degree competitive with antioxidant destruction; and so, from the beginning of the process, an increase in peroxides is accompanied by decay of the antioxidant. Figs. $I$ and 2 demonstrate this clearly. Consider now two corollaries of the hypothesis that the situations in vitro and in vivo are identical. Just as, in vitro, an increase in the unsaturation of the lipid substrate or a decrease in the antioxidant concentration leads to faster peroxidation, so this also should occur in vivo. However, Witting \& Horwitt (1964a,b) produced no evidence that either an increase in the degree of unsaturation of the dietary lipid or a decrease in vitamin $\mathrm{E}$, both of which accelerated the onset of dystrophy, was associated with an increase in lipid peroxidation within muscle or any other tissue. In this and in a previous paper (Bunyan et al. 1967) we have estimated lipid peroxides in a total of twelve tissues of the rat and four tissues of the chick. With the exception of adipose tissue, we have found peroxide values to be unaffected either by the degree of unsaturation of the dietary lipid or by the presence of vitamin E. Bunyan, Green, Murrell, Diplock \& Cawthorne (1968) have shown that the peroxide value of adipose tissue depends on the absorption of preformed dietary lipid peroxides and that the ability of vitamin $\mathbf{E}$ to influence this peroxide value is mediated by an effect on absorption and not by preventing peroxidation in vivo. Indeed, it was found possible to increase the polyunsaturated fatty acid (PUFA) content of adipose tissue by tenfold in the absence of vitamin $E$ without increasing the very small amounts of lipid peroxide usually found in that tissue. It may be argued that the failure to find increased peroxides in tissues such as muscle, uterus, testis and liver, which are primary sites of pathological change in vitamin $\mathrm{E}$ deficiency, is due to the rapid metabolism of the newly formed peroxides. Such an argument (Ghoshal \& Recknagel, I965; Kokatnur, Bergan \& Draper, 1966) is not supported by evidence and, indeed, seems unlikely in view of the constant levels of peroxide found in these tissues irrespective of their vitamin $\mathrm{E}$ status. In contrast, Glavind, Søndergaard \& Dam (I96r) found the metabolism of injected triglyceride peroxide in the chick to be unaffected by vitamin E, and Bunyan et al. (1968) found that the half-life of lipid peroxides in rat adipose tissue was about 6 days and also was unaffected by vitamin $\mathrm{E}$.

The second corollary of the hypothesis is that the destruction of tocopherol in the tissues must be affected by the unsaturation of the tissue lipid and hence of the dietary lipid (Witting, $1965 a$ ). Recently Witting et al. (1965) observed that when rats were depleted of tocopherol on diets containing lipids varying in PUFA content, then those given diets high in PUFA were 'deficient' (i.e. developed creatinuria) at an average body $\alpha$-tocopherol level of $2.4 \mu \mathrm{g} / \mathrm{g}$, whereas those given diets low in PUFA were not 'deficient' (i.e. did not develop creatinuria) even at an average body tocopherol level of $0.4 \mu \mathrm{g} / \mathrm{g}$. They and Witting $\left(\mathrm{I}_{96}{ }^{6} b\right)$ have suggested that this result can be explained, in terms of the antioxidant hypothesis, by assuming that the tissue fatty acids of rats 
given a diet high in PUFA are, relative to $\alpha$-tocopherol, better proton donors to fatty acid peroxy radicals than are the fatty acids of rats given a diet low in PUFA. Therefore, it was argued, at a given tissue tocopherol level there is 'more lipid peroxidation, more cycles of chain reaction, per free-radical initiation in the tissue lipids of the rats fed the high PUFA diet than in the lipids of the group fed the low PUFA diet'. The results shown here in Figs. I and 2 suggest that the explanation advanced by Witting $(\mathrm{I} 965 b)$ is based erroneously on the premise that the situation described in Fig. I is a correct biological model; that is, that the development of disease requires some arbitrary degree of peroxidation in the tissues of the animal and hence that the decay of tocopherol can be discussed in terms of hypothetical cycles of chain reaction necessary to attain equal degrees of peroxidation in animals differing in PUFA content. On the contrary, if the production of the deficiency disease is caused by and is quantitatively related to the incidence of 'lipid peroxidation' in vivo, and if this is mechanistically comparable to peroxidation in vitro, then the rate of decay of the tocopherol dose in each group of animals over the experimental period should correspond to that described in Fig. 2; that is, there must be a greater rate of decay of tocopherol in animals given the more unsaturated diet, and certainly not a lower rate, as Witting's $(1965 b)$ argument might lead us to expect. However, neither Fig. I nor Fig. 2 can be regarded as a model of the true relationship between dietary lipid unsaturation and vitamin $\mathrm{E}$ metabolism in vivo; for administration of lipids differing in PUFA content even for long periods does not, in fact, affect at all the rate of $\alpha$-tocopherol destruction in vivo, either in rats (Green et al. 1967) or in chicks (Diplock, Bunyan, McHale \& Green, 1967 ). It is important to note that when Witting et al. (1965) studied the depletion of whole body tocopherol levels over 12 weeks in rats given diets differing in PUFA content, they too could find no effect of PUFA on the rate of depletion. Their results and ours are therefore in agreement. Their interpretation in terms of 'lipid peroxidation' and the antioxidant theory, however, is incompatible with both sets of results, and it would seem that the existence of 'deficiency' disease at varying tocopherol levels, depending on the PUFA content of the diet, may be better understood in terms of an increased tocopherol requirement in animals given increased amounts of unsaturated fatty acids.

\section{REFERENCES}

Bligh, E. G. \& Dyer, W. J. (1959). Can. Y. Biochem. Physiol. 37, 9 I x.

Bunyan, J., Green, J., Murrell, E. A., Diplock, A. T. \& Cawthorne, M. A. (1968). Br. F. Nutr. 22, 97. Bunyan, J., Murrell, E. A., Green, J. \& Diplock, A. T. (1967). Br. F. Nutr. 21, 475.

Cawthorne, M. A., Diplock, A. T., Muthy, I. R., Bunyan, J., Murrell, E. A. \& Green, J. (1967). Br. F. Nutr. 21, $67 x$.

Diplock, A. T., Bunyan, J., McHale, D. \& Green, J. (1967). Br. F. Nutr. 21, I03.

Folch, J., Lees, M. \& Stanley, G. H. S. (I957). F. biol. Chem. 226, 497.

Ghoshal, A. K. \& Recknagel, R. O. (1965). Life Sciences 4, I 52 I.

Glavind, J., Søndergaard, E. \& Dam, H. (196I). Acta pharmac. tox. 18, 267.

Green, J., Diplock, A. T., Bunyan, J., McHale, D. \& Muthy, I. R. (1967). Br. F. Nutr. 21, 69.

Horwitt, M. K. (1962). Vitams Horm. 20, 54r.

Kokatnur, M. G., Bergan, J. G. \& Draper, H. H. (1966). Proc. Soc. exp. Biol. Med. 123, 254.

Lips, H. J. (1957). F. Am. Oil Chem. Soc. 34, 513.

Oette, K. (1965). F. Lipid Res. 6, 449.

Society for Analytical Chemistry: Analytical Methods Committee (1959). Analyst, Lond. 84, 356.

Tappel, A. L. ( (962). Vitams Horm. 20, 493. 
Witting, L. A. (1965a). F. Am. Oil Chem. Soc. 42, 908.

Witting, L. A. (1965b). Fedn Proc. Fedn Am. Socs exp. Biol. 24, 912.

Witting, L. A., Harmon, E. M. \& Horwitt, M. K. (1965). Proc. Soc. exp. Biol. Med. 120, 718.

Witting, L. A. \& Horwitt, M. K. (1964a). Y. Nutr. 82, I 9.

Witting, L. A. \& Horwitt, M. K. (1964b). ₹. Nutr. 84, 35 I. 